\title{
The University in Public Service: Some Reflections*
}

\author{
DUNCAN D. CAMPBELL**
}

\begin{abstract}
University public service, which takes a variety of forms, criticism and extension among them, is the least well rewarded of the institution's principal functions. Yet, of all organizations in society, the university has a special responsibility to identify social problems and to help resolve them. It is proposed that Canadian universities ought now to take the initiative, in consultation with leaders in both government and the community, towards determining through what mechanisms publicly-provided university resources can most effectively be deployed in a public service thrust towards the improvement of the quality of Canadian life.
\end{abstract}

\section{RÉSUMÉ}

L'Université dans le domaine du service public: quelques réflexions

Le service public au sein de nos universités, prenant une variété de formes, $y$ inclus, la critique et les cours publics sous les auspices de l'université, est la fonction la moins récompensée de cette institution. Pourtant, de toutes les structures dans la société, l'université a une responsabilité spéciale d'identifier les problèmes sociaux et d'aider à les résoudre. L'auteur propose que les universités canadiennes doivent prendre actuellement l'initiative, de concert avec des personnalités dirigeantes du gouvernement ainsi que de la communauté, pour déterminer quels sont les mécanismes qui permettraient le meilleur déploiement de ressources publiques universitaires pour améliorer la qualité de la vie canadienne.

Were one to invite the public's judgment of the priority appropriate to the principal functions of the Canadian university, the answer would probably be teaching, research, and public service. Were the same question put to the academics of its universities, that order would likely shift to research, teaching, and - if it were mentioned at all - public service. To establish the fact of the matter, one would turn immediately to the rewards system of the university. With respect to these three functions, where does the university bet its chips?

*From an address to the Institute of Public Administration, Canada, Edmonton Region.

**Professor of Higher Education, The University of Alberta. 
In fact, the university's reward system puts research in first place. The path to promotion for the academic - excepting those who seek a place in the sun from a rung on the administrative ladder - is through published research. In assessing claims to promotion, on a merit scale running from zero to a high of ten, research would be valued at, say, nine, teaching at about three, and public service - were it reckoned at all - at one.

There are compelling reasons for this pre-eminence of research over teaching and public service in the institutional reward system. Within the university, fields of knowledge are largely compartmentalized in departments. In fact, departmentalization is easily the most significant structural feature of the organization of the university throughout the western world. What the citizen taxpayer may not appreciate is that, while departments strive one with another within the university for funds and prestige, the foremost arena of competition for members of a department is typically world-wide. Physics, clearly is not physics just at this institution or at that. As a science it is world-wide and competition among physicists is world-wide. That competition is conducted, for the most part decorously, through research results published in international journals. The reputation of the individual physicist, therefore, is not pieced together on one campus, or this province, or that country, in reflection of a flair for teaching or for service to the community. It is nurtured in a world-wide market where gains and losses are registered in the tables of content of international journals. Thus, while the citizen might be under the impression that the first job of the university professor is to teach, the fact is that research is the job component which puts the academic close to the purse.

Which is not, of course, to suggest that teaching is dismissed as unimportant - or that the university does not have its good teachers; and there is clear agreement that good teaching goes hand in glove with vital research. But despite its importance, preparing academics to teach is not a problem to which the university has given more than passing attention. The tacit assumption is that somehow, in the acquisition of a doctorate, one has acquired the gift of transmitting knowledge and a passion for learning to others. But, as many a student will testify, bitterly or in resignation, this is often far from the truth. It is only in the last half-dozen years that some few Canadian universities have created institutes within themselves to investigate university teaching and to help the staff member acquire some measure of skill in his teaching responsibilities. There remain those who hold that facility in teaching is not thus to be acquired but, rather, is innate, a skill unlikely to be acquired through training. But as others see it,

... to claim that the experience of the experienced is all of such a personal idiosyncratic kind that it cannot possibly be analysed, systematised and passed on to relative beginners . . . is clearly nonsense, and arrogant nonsense at that. ${ }^{1}$

What of the university's role in public service? One might begin by looking at the university in its public service role as critic of society.

That flamboyant Canadian expatriate, John Kenneth Galbraith, once remarked that the principal ingredients of the memorable speech were fanciful exaggeration, foolish prophecy, and silly heroics coupled, on occasion, with a resort to extreme piety. That clever petulance doesn't apply to an address delivered by the University of Toronto's D. B. MacPherson to Newfoundland's Memorial University, which states with charm and 
grace the notion of the university as critic of the society which nurtures it. Briefly, it is that society has a right to expect the university to perform a useful social function appropriate to it. That task is diagnosis.

What a sick society needs most is diagnosis, at every level of its malfunctioning: ecological, physiological, economic, psychological, political, and above all (or below all), to use an old-fashioned word in little repute these days, moral. It needs diagnosis not just of what has gone wrong with its mechanism, but has gone wrong with its values. ${ }^{2}$

The proper role for the university is that of "multiple fool". Likening the university to the jester of old - but, in this instance, a Hydra-headed jester - MacPherson argues that the proper part of the university is to strip the pretensions from society's modern courtiers. And they are legion, among them businessmen cloaked in the stridently proclaimed virtues of free enterprise who scheme to use the favours of government to increase profits or labour leaders who skilfully exercise a minority's tyranny to further minority interests or professionals who harness societal need to forwarding personal advantage. The task, in short, of this multiple jester is to tell the truth, displeasing though it may be. From what platform better than the campus can this be done?

This ideal is not new. Abraham Flexner, that iconoclast of higher education, argued a half-century ago that universities - and it is the assembly of academics within each which is the university - must maintain contact with the real world, must take an objective position in reference to social, political, and economic phenomena - while at the same time remaining irresponsible. ${ }^{3}$ Claude Bissell, too, one of Canada's small clutch of intellectuals, echoes the theme in his judgment of the university as a critical institution with a clear obligation to give guidance and direction to society. Yale's William Sloane Coffin sees the relationship between university and society as that of a lovers' quarrel, with the accent equally on lover and quarrel.

What bounds this obligation of dissent? Is it simply a matter of occasional public comment by interested academics? Is it dispute to be hidden between the covers of scholarly journals seen only by academic peers on matters remote from public concern? Or is it meant, somehow, to be integrated into teaching and to stimulate research?

Some Canadian academics hold that dissent is a part of all university functions. The job of higher education is not to solve problems but to create them. The university, alone in the community, so the notion goes (ignoring the media) has the responsibility for objective criticism. That criticism, in the main, is exercised through the student. The job of the university is to help the student to educate himself as a unique self, to assist him to relate himself to his culture, to other cultures, to help him to fix in his own mind the character of national problems so that, as a citizen, he can exert an intelligent pressure for their analysis and solution. Thus trained, the student is appropriately pointed on a collision course with conventional wisdom, traditional morals, and contemporary institutions.

One point deserves clarification: whether it is the institution which is to function as critic - or its individual members. Clearly, it is one thing for academics as individuals to play the critic's role; it is quite another for the institution itself to do so. The lesson of the University of California's experience in the 1960's for Canada is that if the academic community chooses to use the university as a base for political action, if it attempts to 
identify the university with its causes or to mobilize its prestige and resources in support to its institutional goals, then the university itself will inevitably be politicized. But on the other hand, there is equal force in a Carnegie Foundation statement that

... among all institutions in the nation, the university has the greatest responsibility to be a shaper of the society. As such it has an obligation to identify social wrongs and take an aggressive lead in rectifying them. ${ }^{4}$

There are thus twin dangers which neither the state nor university can risk: alienation from society or too close identification with it. In any event, diagnosis of a sick society is only a first step. To continue the medical analogy, it must be followed by prescription. Not only must problems be identified but remedies must be proposed.

On that point, what of the expectation that academics might themselves undertake some questioning of received wisdom concerning the functioning of their own institutions - which are in difficult times? It is perhaps the greatest single weakness of the Canadian university that so little provision is made within it for considering fundamental questions of educational policy, in dialogue with the society, problems quite aside from those of institutional maintenance and routine operation. Its more sardonic critics say of it that the methods of social research have been applied by academics to every institution but their own. In consequence, one speculates whether the direction of educational change is not more the product of pressure than of planning and of outside influence than of statesmanship.

That aside, no other of society's institutions has that degree of detachment, of neutrality, of strength in resources, to function as social critic, as "multiple jester", a role which makes stern demands on the university of

intellectual wakefulness [which expresses] itself through penetration, analysis, and criticism - through individuality and the willingness not to conform even through outright heresy and rebellion, but not through uncritical acceptance of prescribed policy, whether of corporation, Church or government. ${ }^{5}$

It is one thing to sketch this role of critic. A fair question is whether academe has come even close to performing it. Paul Gerin-Lajoie, Quebec's sometime minister of education, declares in categorical fashion that the university

... has remained on the edge of this vast movement of critical evaluation and transformation: its academic and administrative structures, with the exception of a few minor changes, have remained petrified in the traditional mould. Instead of being, as it claims to be, the heart and source of new ideas and progress, the university sets the example of an institution that waits for crises and violent confrontations to transform it. ${ }^{6}$

Nor, indeed, is it invariably conceded that universities have the competence to function as critic. Take as witness, one with a varied and newsworthy experience, a former Attorney General of the United States. "The professors," he fulminates, "are just as bad [as the students] if not worse. They don't know anything nor do those stupid bastards who are running our education institutions." 7

One may conclude that it is not, today, nearly enough for the university to stand aloof, 
to dispense cool and dispassionate criticism from a place on the periphery of events. On the contrary, it must climb down from its ivory tower and, in sports jargon, mix it up in the market place. Regrettable as it is true, there lingers in the public mind the nagging suspicion that universities have still to catch up to 1970, that society's needs have moved beyond those which can be served by the classic institution of the last century so movingly evoked by Cardinal Newman. What the public can be heard to demand from its universities is an active, helping role in the community.

It is true that university extension divisions in Canada have energetically and productively linked town and town with programs of continuing education. University extension, in Canada generally and in Alberta in particular, as an ingredient in university public service, has had a tremendous, positive impact on public education. Its educational projects, often of the highest quality, are characterized by imagination coupled to a shrewd understanding of where the education action is really at. It is ostrich-like to ignore the objective evidence of the significance of this kind of education as academics sometimes like to do. Recent Statistics Canada data show that the participation rate by citizens in non-credit courses offered by Alberta universities, for example, is 17.3 per thousand. That is an authoritative index of citizen desire to use the resources of the university - his university - which it is folly, surely, to ignore. Part-time students rather than full-time students as of 1974 dominate the student population.

But noting that, let it be added that what is required is not only a more generous elaboration of these educational services to the public through university extension, important as they are. What is wanted is not merely an extension of extension but a deliberate and forceful application of the expertise of the university - perhaps with the partnership of government and community - to the real problems of society. In some way, through a variety of mechanisms, university brains, university facilities and university knowhow must be harnessed to the solution of the real problems, the desperate problems, of this society: of transportation, of environmental control, of poverty, of housing, which stick in Canada's guts. It is these problems in which the university must involve itself if it is to remain vital and relevant as a teaching and research agency and if it is to avoid being relegated to the sidelines by time and events. The University of Alberta's proposed Management Institute is illustrative of the approach.

What is needed in public service from the university is not mere crumbs from the academic table, furnished by the taxpayer - and certainly no more of the woolly rhetoric of the convocation platform. Rather, what the times demand is the solid application of university resources, of university leadership, to the vital issues of our day. The time is ripe, now, for the prime movers within university, in whatever niche they function, to meet with leaders in government and leaders in the community to determine through what mechanisms the institution can best apply its publicly-provided reservoir of skills to improving the quality of Canadian Aife.

This ought now to become the focal point of university public service. 


\section{Footnotes}

1. National Institute of Adult Education, "Recruitment and Training of Staff for Adult Education," Adult Education, (London: March 1966), p. 366.

2. C. B. MacPherson, "The University as Multiple Fool," CAUT Bulletin, Vol. 19, No. 1 (1970), pp. 2-7.

3. Abraham Flexner, Universities: American, English, German (New York: Oxford University Press, 1968), p. 15.

4. Carnegie Foundation for the Advancement of Teaching, Sixty-Second Annual Report for the Year Ended June 30, 1967 (New York: The Carnegie Foundation for the Advancement of Teaching, 1967), p. 14.

5. J. Percy Smith, unpublished paper, University of Guelph, 1973.

6. Paul Gérin-Lajoie, Quebec's former Minister of Education, as quoted in The University, Society and Government, Report of the Commission on the Relations Between Universities and Governments, Rene Hurtubise and Donald C. Rowat, Commissioners (Ottawa: University of Ottawa Press, 1970), p. 41.

7. John Mitchell, Attorney General of the United States, as quoted in Time, circa January, 1971. 